\title{
96 $\mathrm{XXV}$ Congresso de Iniciação Científica da Unicamp
}

18 a 20 Outubro Campinas | Brasil

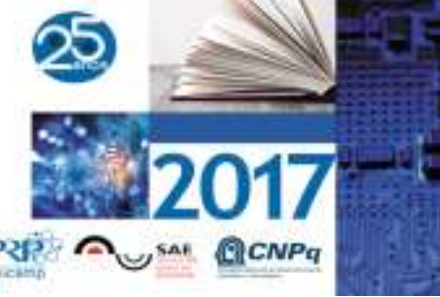

\section{Cultivo de plantas para ensino, pesquisa e para o Jardim Botânico da UNICAMP}

\section{Bolsistas: Analice Xavier Guedes, Letícia Delgado Miranda, Luana de Oliveira Sousa. Orientadora: Maria do Carmo E. Amaral.}

\section{Resumo}

O objetivo do projeto é conhecer e cultivar as plantas que irão fazer parte das coleções de plantas vivas do futuro Jardim Botânico da UNICAMP. Foram feitos registros fotográficos das plantas antes e durante a floração. Elaboramos experimentos com plantas úteis para observar e comparar o seu crescimento em diferetes condições de solo.

\section{Palavras-chave:}

Jardim Botânico, Cultivo experimental de plantas, Plantas úteis.

\section{Introdução}

Um Jardim Botânico é uma coleção de plantas ordenadas cientificamente, geralmente documentadas e etiquetadas. Essas plantas cultivadas devem demonstrar uma ampla diversidade de formas de vida e fornecer informações sobre sua biologia e a importância das plantas para a sociedade. Nosso principal objetivo foi cultivar plantas úteis, das quais são conhecidas, principalmente, as suas sementes, como a lentilha, o grão-de-bico e o gergelim, por exemplo.

\section{Resultados e Discussão}

$\mathrm{Na}$ casa de vegetação, cuidamos das plantas suculentas e fizemos cruzamentos entre elas para produzirem frutos e sementes. Plantamos algumas espécies úteis, que chegaram a florescer e produzir sementes. Fizemos também experimentos de cultivo com duas espécies, o quiabo e o gergelim, plantando as sementes em vasos com diferentes tipos de solo: um com terra vegetal e outro com areia (pobre em nutrientes). Como resultado, as plantas cultivadas na terra vegetal cresceram muito mais do que as cultivadas em areia. Muitas vezes, as plantas cultivadas foram atacadas por pulgões, ácaros e besouros, e o controle dessas pragas foi uma tarefa importante do nosso trabalho. Outra tarefa importante que realizamos foi salvar uma planta de Amorphophallus $\mathrm{sp}$. que estava soterrada sob uma grande quantidade de terra de descarte, impossibilitando o seu brotamento. Essa espécie é a que possui a maior inflorescência, semelhante a uma grande "flor". Coletamos muitas espécies dentro da UNICAMP, aprendendo a documentar e prensar o material, para posteriormente ser incluído no herbário. Uma das plantas coletadas foi o pau-brasil.

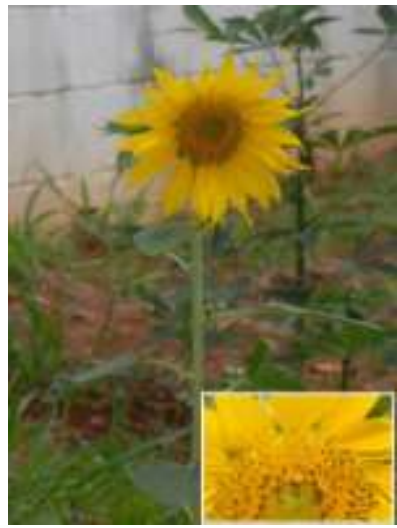

Girassol

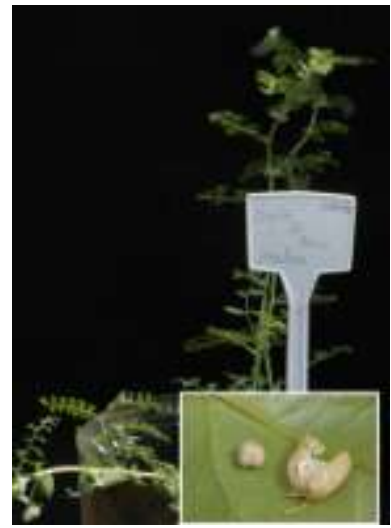

Grão-de-bico

\section{Conclusões}

Durante todo o período do projeto, aprendemos que as plantas merecem todo o cuidado possível e que são capazes de nos trazer muitos benefícios. Nós tivemos a oportunidade de conhecer variadas plantas das quais suas sementes estão presentes no nosso dia-a-dia, mas a sua planta é desconhecida para a maioria das pessoas. Muitas coisas que fizemos no projeto estarão disponíveis como informações no futuro Jardim Botânico da UNICAMP.

\section{Agradecimentos}

Agradecemos à Pró-Reitoria de Pesquisa da UNICAMP pela oportunidade do projeto, ao $\mathrm{CNPq}$ pelas bolsas, ao FAEPEX pelo apoio, e à orientadora Maria do Carmo $\mathrm{E}$. Amaral pela dedicação.

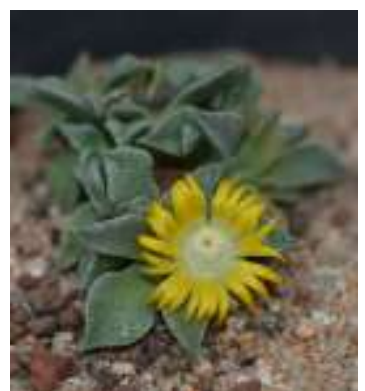

Planta suculenta

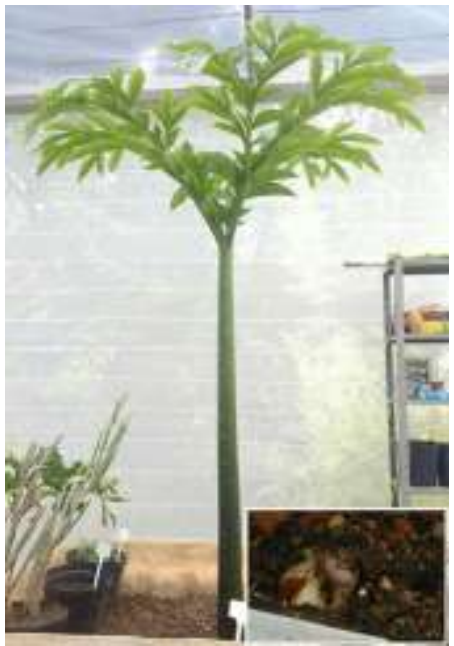

Amorphophallus sp.

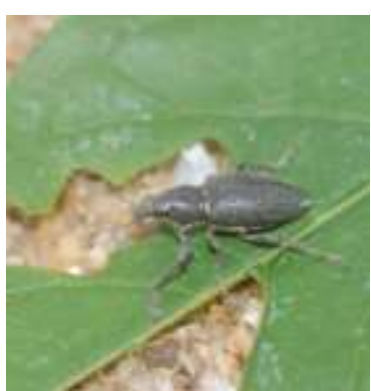

Besouro comendo folha

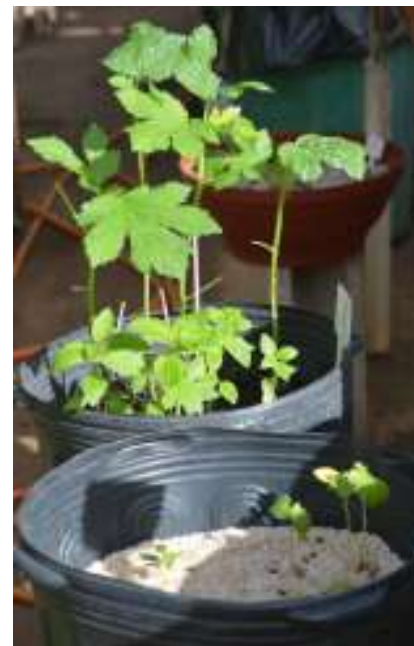

Cultivo experimental 